\title{
Ten Thousand Years of Experience with Sustainable Plant Disease Control
}

\author{
H. David Thurston
}

We are confronted daily with images of terrorism and poverty. The gap between the "haves" and the "have-nots" seems to become greater every day. Surely, there is a correlation between this gap and terrorism. Can a study of the human experience with agriculture possibly influence a reduction of terrorism and poverty? Gandhi (2) called poverty the worst form of violence.

Archeologists believe that humans began crop production perhaps 10,000 years ago. I cannot confirm that sustainable disease control practices began that long ago, but sustainable disease control practices did certainly evolve as agriculture developed. Many of the successful practices of ancient farmers have been forgotten or abandoned in developed countries, but still are used by many traditional, indigenous, subsistence, or partially subsistence farmers. Most of the useful practices and materials used in agriculture probably were developed empirically through millennia of trial and error, farmer selection, and keen observation. Fallowing, a well-known sustainable plant disease practice, has been used for thousands of years. In the Middle East, in what is now Iraq, the ancient Sumerians, one of the world's oldest civilizations, practiced fallowing for their cereal fields (5). Sumerians flooded their fields before plowing and also puddled them with oxen (6). A sabbatical year in which, for one year, farmers were not allowed to plant crops, was mandated in ancient Jewish religious law. Exodus 23:10-11 reads: "For six years you shall sow your land and gather in its yield; but the seventh year you shall let it rest and lie fallow."

The paddy system may be one of the oldest sustainable agricultural practices. Traditional farmers have flooded their rice paddies for millennia. Rice grown in this system has annually produced a ton or two of paddy per hectare, without high inputs of fertilizer or pesticides. Chinese writings in 3,000 B.C.E. mentioned rice as an important food (4), but rice may have been first domesticated in Thailand about 3,500 B.C.E. (3). Flooding is a plant disease

Accepted for publication 27 July 2003.

Publication no. D-2004-0209-010

(c) 2004 The American Phytopathological Society management practice still in use for various plant diseases today (7).

For millennia, farmers have restricted or endured plant diseases with little if any reliance on external or synthetic inputs. For thousands of years, ancient farmers developed sustainable agriculture practices that allowed them to produce food and fiber and manage pests and plant diseases. Practices used include altering of plant and crop architecture, biological control, burning, adjusting crop density, depth or time of planting, planting diverse crops, fallowing, flooding, mulching, multiple cropping, planting without tillage, using organic amendments, planting in raised beds, rotation, sanitation, and manipulating shade (8). Most of these practices were sustainable in the long term. This traditional knowledge can play an important role in developing a sustainable agricultural base for the future.

Should we be interested in the history of sustainable plant disease control? We can learn much from the practices of traditional farmers in order to elucidate principles and methods useful in the future management of agriculture. Wilken (9) noted some of the reasons why the agricultural activities of traditional farmers are worthy of study. For example, some traditional farming systems have excellent records in resource management and conservation. Those systems that have lasted for thousands of years surely justify serious study not only by archeologists, but also by plant pathologists. On the other hand, some of the practices and systems developed by traditional farmers were not successful and led to ecological disasters. Perhaps we can learn from their mistakes. Today, there are many concerns about "modern agriculture" because it is energy intensive, its genetic base is narrow, its goals of increasingly high yields and efficiency lead to monoculture (which is not necessarily bad), overproduction, and sometimes, excessive erosion, pollution, and serious pesticide residues.

The term "traditional" usually is associated with primitive agricultural systems or pre-industrial peasant agriculture. Traditional farming usually is based on knowledge of practices that have been passed down for many generations. Traditional knowledge can be overvalued or romanticized, but that is far better than despising or ignoring it. Far too many giant development projects in developing countries have failed dismally and have caused serious ecological problems because they lacked sufficient understanding of traditional or indigenous agriculture. Often, traditional practices are effective and sustainable. Traditional practices and cultivars (landraces) have had a profound effect on "modern agriculture" and most of our present practices and cultivars evolved from these ancient techniques and plant materials. Until recently, agricultural development programs designed to improve traditional food production systems generally have dictated purely technological solutions to problems that are also environmental, cultural, social, and economic in nature. A tragic result often has been a mismatch of development objectives to the needs and potentials of local people. To remedy and avoid such tragedy, a better understanding of traditional agriculture by development planners is needed. Combining the best of traditional agriculture practices with the best of modern agriculture could go a long way toward improving the lives of poor people living in less-favored regions. Most of the practices traditional farmers used for millennia to control plant diseases were simply good agronomic practices.

I want to emphasize that knowledge of traditional agriculture will not solve the world's food problems. The management of intensive farming systems in irrigated and high-potential agricultural areas is relatively well understood, but much less is known about the problems of poor people living in less-well-endowed regions. These are often in environmentally sensitive areas with limited agricultural potential because of low soil fertility, steep slopes, or meager water resources, and usually with poor infrastructure and service support. Degradation of agriculture in poor rural areas is closely linked to low land productivity, poverty, and food insecurity. Many of the people living in these disadvantaged areas are still surviving by using traditional knowledge handed down from their ancestors.

Today, much of the rhetoric in agriculture emphasizes "sustainability" and "biotechnology". Although these terms are vague and all encompassing, they strongly effect current funding and research directions. Increasing population pressure, as- 
sociated environmental degradation, changes in land tenure patterns, and socioeconomic conditions are forcing many farmers to modify their farming systems in order to survive. The sustainability of agricultural production in the tropics, particularly within farming systems of resourcepoor farmers, continues to erode as these changes take place, the average farm size decreases, and farmers are forced onto increasingly marginal lands by worsening socioeconomic and political conditions. In conjunction with the associated increase in rural poverty, these changes have resulted in reduced yield stability and fallow length, which in turn have led to field abandonment and, occasionally, irreparable environmental degradation. Accompanying agricultural problems include reduction in soil fertility, which is exacerbated by soil erosion, loss of organic matter, nutrient leaching, and sometimes an increase in weeds, diseases, insects, and other pests.

Traditional agriculture represents the labor of millions of humans and the management of millions of hectares, and even small improvements would be significant for the world as a whole. For planners in developing countries, traditional methods have some advantages over modern agri- cultural techniques. For example, capital and technological skill requirements of traditional technologies are generally low, and adoptions often require little restructuring of traditional societies. Also, because modern agriculture has developed primarily in temperate regions, the adoption of practices that are acceptable in these countries may have unexpected and undesirable impacts in developing countries, especially those found in the tropics.

No one is suggesting that we should go back to more primitive methods of agriculture because chemicals are bad or modern genetics is bad. This is not true. The science and technology being developed today is necessary in order to feed the world and its rapidly growing population. Many authorities, such as Borlaug (1), have pointed out that the more yield we get per unit of land the less the environment has to be destroyed. Nevertheless, contrary to some conventional wisdom, investing in strategies that intensify sustainable agricultural for the rural poor in less-favored areas also can make important contributions to resolving some critical global environmental problems, while at the same time bringing improved livelihood and rural poverty reduction for large numbers of some of the poorest people. Although it is unlikely to eliminate all hunger in the world, the use of traditional farming knowledge in the less-favored regions of the world can go a long way toward reducing poverty. And perhaps terrorism will also fade a bit.

\section{LITERATURE CITED}

1. Borlaug, N. http://www.onlineopinion.com.au/ 2002/May02/Borlaug.htm

2. Gandhi, M. http://www.cyber-nation.com/vic tory/quotations/subjects/quotes_povertyandthe poor.html

3. Grigg, D. B. 1974. The Agricultural Systems of the World: An Evolutionary Approach. Cambridge University Press, Cambridge.

4. Grist, D. H. 1975. Rice. Longman, London.

5. La Placa, P. J., and M. A. Powell. The agricultural cycle and the calendar at Pre-Sargonic Givsu. Bull. Sumerian Agric. 5:75-104

6. Maekawa, K. 1990. Cultivation methods in the Ur II period. Bull. Sumerian Agric. 5:115-145.

7. Stover, R. H. 1979. Flooding of soil for disease control. Pages 19-28 In: Soil Disinfestation. D. Mulder, ed. Elseveir Science Publications, Amsterdam.

8. Thurston, H. David. 1992. Sustainable Practices for Plant Disease Management in Traditional Farming Systems. Westview, Boulder, CO.

9. Wilken, G. C. 1974. Some aspects of resource management by traditional farmers. Pages 47-59 in: Small Farm Agricultural Development Problems. H. H. Biggs, and R. L. Tinnermeir, eds. Colorado State University, Fort Collins. 